\title{
JAWABAN SOAL UTS 2018/2019 MATAKULIAH PEMROGRAMAN BORLAND DELPHI
}

\section{APRILIA PUTRI \\ 165100010}

Fakultas Komputer, 448757257

Apriliaputria.student@umitra.ac.id

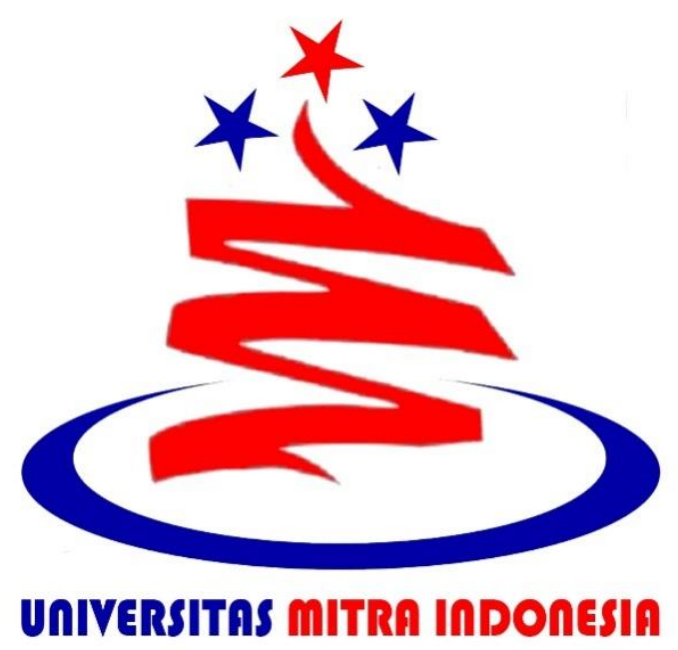




\section{A. STUDI KASUS ( SK )}

Pertanyaan Type C :

Pilih lah Salah Satu Logo

Software Anggota Time di

Paparkan dan di Jelaskan.

\section{Jawaban:}

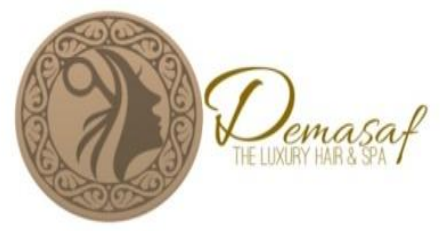

Terdapat siluet wajah wanita dan rambut di $\log 0$ tersebut menunjukkan bahwa DEMESAF adalah salon khusus wanita.

Border lingkaran yang ada di sisi logo menggambar kan kesan mewah,karna salon DEMASAF adalah salon yang mengusung kemewahan.

Warna gold (Emas)

Warna emas yang di berikan pada logo menunjukkan kesan mewah dan berkelas.warna emas juga memiliki warna kesuksesan,kemenangan dan juga kemakmuran.

\section{B. STUDI REFERENSI ( SP )}

Pertanyaan Jenis B :

Carilah Perbedaan Utama Borland Delphi 6.0 dan Borland Delphi

Pegangan gunting yang Embarcandero.

terdapat pada logo tersebut menggambarka n,bahwa DEMASAF adalah salon yang berkompeten di bidang nya yaitu tata kecantikan rambut.

\section{Pejelasan Logo:}


berorientasi pada objek yang menarik produk Borland pascal 7.0(with objek).

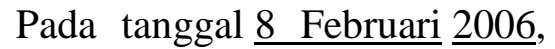
Borland mengumumkan akan melepas seluruh jajaran produk pengembangan aplikasi komputernya termasuk di antaranya Delphi, untuk itulah Borland membentuk perusahaan baru dengan nama CodeGear sehingga terpisah dari Borland [1]. Saat ini Delphi menjadi bagian dari jajaran IDE milik Embarcadero Technologies setelah Embarcadero Technologies mengakuisisi CodeGear. Hal ini disebabkan karena kerugian yang terus menerus selama 2006 rugi bersih sebesar \$53.1 juta, 2007 rugi bersih $\$ 61$ juta. Sehingga pada tahun 2008 saat CodeGear menderita rugi bersih[2]. $\$ 22.3$ maka CodeGear dijual ke Embarcadero seharga \$23 juta untuk menutupi rugi bersih ini.

\section{STUDI PENALARAN( SP )}

Pertanyaan Kategori 3 :

\section{Buatlah Algoritma Sederhana} Mengguna kan Flowchat (Pembayaran Kampus Anda).

Jawaban:

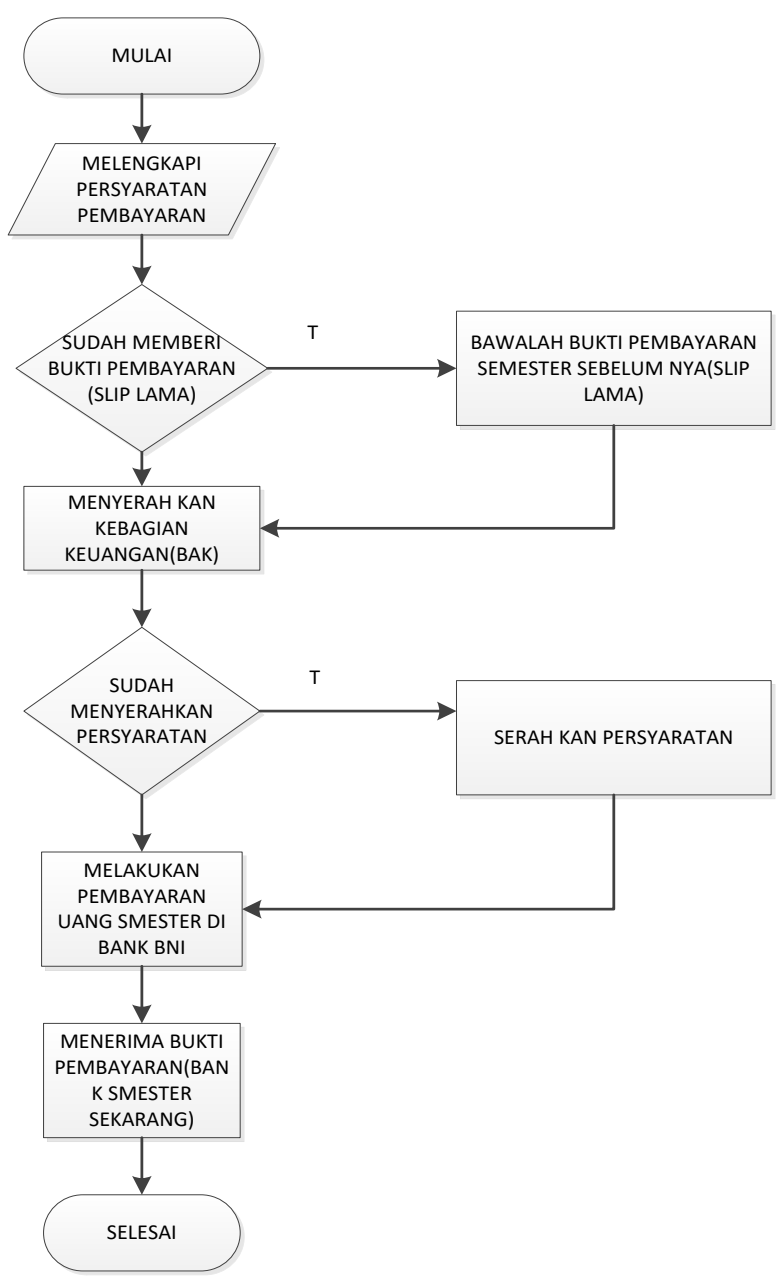




\section{REFERENSI}

[1] A. S. Putra And O. M. Febriani, "Knowledge Management Online Application In Pdam Lampung Province," In Prosiding International Conference On Information Technology And Business (Icitb), 2018, Pp. 181-187.

[2] A. S. Putra, O. M. Febriani, And B. Bachry, "Implementasi Genetic Fuzzy System Untuk Mengidentifikasi Hasil Curian Kendaraan Bermotor Di Polda Lampung," J. Sist. Inf. Dan Manaj. Basis Data, Vol. 1, No. 1, Pp. 21-30, 2018.

[3] O. M. Febriani And A. S. Putra, "Sistem Informasi Monitoring Inventori Barang Pada Balai Riset Standardisasi Industri Bandar Lampung," J. Inform., Vol. 13, No. 1, Pp. 90-98, 2014. [4] Putra, Arie Setya. "2018 Artikel Struktur Data, Audit Dan Jaringan Komputer." (2018).

[5] Putra, A. S. (2018, July 17). Paperplain Fundamental Create Application With Borland
Delphi 7.0 University Of Mitra Indonesia. Retrieved From Osf.Io/Pbrn9. 